\title{
Corrigendum
}

Genome Research 26: 732-744 (2016)

Corrigendum: Large-scale analysis of genome and transcriptome alterations in multiple tumors unveils novel cancer-relevant splicing networks

Endre Sebestyén, Babita Singh, Belén Miñana, Amadís Pagès, Francesca Mateo, Miguel Angel Pujana, Juan Valcárcel, and Eduardo Eyras

The authors would like to correct the inadvertent omission of a funding source in the Acknowledgments section of the initial publication of this article. The corrected text is as follows and has been updated online:

"The work performed in the laboratory of J.V. was also supported by the European Research Council (ERC AdG - GA670146 - MASCP)."

doi: $10.1101 /$ gr.242214.118 


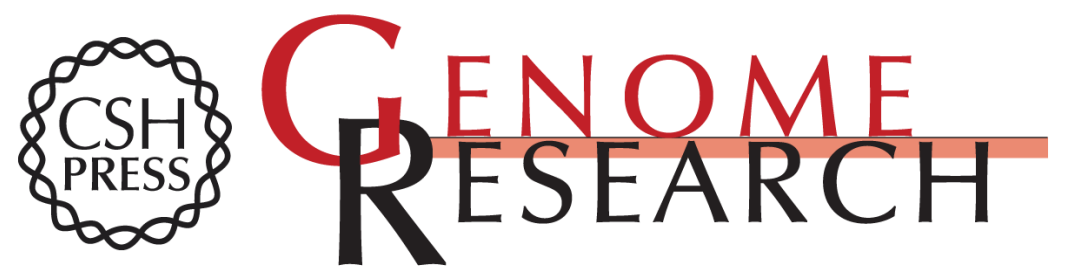

\section{Corrigendum: Large-scale analysis of genome and transcriptome alterations in multiple tumors unveils novel cancer-relevant splicing networks}

Endre Sebestyén, Babita Singh, Belén Miñana, et al.

Genome Res. 2018 28: 1426

Access the most recent version at doi:10.1101/gr.242214.118

Related Content Large-scale analysis of genome and transcriptome alterations in multiple tumors unveils novel cancer-relevant splicing networks

Endre Sebestyén, Babita Singh, Belén Miñana, et al.

Genome Res. June , 2016 26: 732-744

Open Access Freely available online through the Genome Research Open Access option.

License

Email Alerting Receive free email alerts when new articles cite this article - sign up in the box at the Service top right corner of the article or click here.

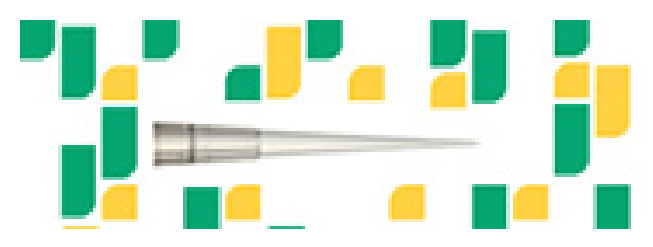

Focused on your science.

To subscribe to Genome Research go to:

https://genome.cshlp.org/subscriptions 